\title{
Shear Strength Characteristics of Cemented Clayey Sand Soil
}

\author{
Mostafa A. El Sawaf ${ }^{1}$, Ahmed M. Nasr ${ }^{1}$ and Mona H. Bayoumy ${ }^{2}$ \\ ${ }^{1}$ Geotechnical Engineering, Faculty of Engineering, Tanta University, Egypt \\ E-mail: mostafa.elsawwaf@f-eng.tanta.edu.eg,ahmed.masr@f-eng.tanta.edu.eg, \\ ${ }^{2}$ Research student, Faculty of Engineering, Tanta University, Egypt \\ E-mail: mona_Hussien@f-eng.tanta.edu.eg
}

\begin{abstract}
Several techniques of soil stabilization are available to improve the behavior of many types of soil. The addition of cement to soils have proved a significant effect on the geotechnical properties of treated soils. In this study, an artificial clayey sand soil samples were prepared by mixing $20 \%$ kaolin clay of fine sand. Initially, compaction tests were conducted on soil mixture to study the effect of kaolin addition on maximum dry density, optimum moisture content of mixed soil at a relative density of $55 \%$. The mixed soils were improved by cement. Then ,a series of unconfined compression tests were performed to clarify the performance of improved soil with different cement contents at the optimum water content of each cement content, and the samples examined after two hours from preparation, and curing period of 7 days and 14 day. Results of compaction test indicate that adding kaolin increasing maximum dry density and moisture content. Tests results show that addition of cement to soil mixture increased stiffness and unconfined compression strength (UCS), and leading to a brittle behavior.
\end{abstract}

Keywords: cement stabilization, fine sand, kaolin clay, compaction, unconfined compressive strength .

\section{INTRODUCTION}

Soil reinforcement is one of the most common ground improvement techniques. The main advantages of the soil reinforcement method are time saving, ease of construction and overall economy. Availability of different materials and methods are also important advantages. Fiber acting as root behavior which binds the soil particles together preventing the movement of soil particles. The technique utilized for enhancement of the properties of soil are known as ground improvement techniques.

Ground improvement can be done by some mechanical method, through soil reinforcement or by adding some admixtures in the soil. Suitability of particular methods depends upon the site condition and economy. There are three methods to give reinforcement to the soil. First is by physical method which is done by vibration, thermo-electrical, freeze and thaw. Second is by mechanical method using fibrous materials from geo-synthetic family (Geo-grid, Geotextile, geocomposite, Geo-net, and Geo-cell) or randomly distributed fibers including natural fibers, man-made fibers and mineral fibers. The third is by chemical method using conventional materials ;(cement, lime and bitumen), enzymes, and polymeric resins. This paper investigates the resultant strength and ductility behavior when cement is used to reinforce and stabilize an artificial clayey sand soils. There are numerous past papers published on the topic of cement stabilizing of soils. Consoli, 1998[1] studied the influence of fiber and cement addition on behavior of sandy soil. They reported that; the fiber reinforcement increased the peak and residual triaxial strength and decreased stiffness; however, the increase in residual strength was more efficacious when the fiber was added to cemented soil. Asskar and samman, 2016[2] studied the effect of adding PVA fiber and cement on sand soil to investigate failure modes of specimens, Tests results show that addition of cement to sand increased stiffness and unconfined compression strength (UCS), and leading to a brittle behavior. Moreover, addition of PVA fibers to cemented sand increased the UCS and axial strain at peak strength and increased softening stress. The investigation on clayey sand is very limited. So, this study was performed to evaluate the chemical effect (hydration reaction) of cement clayey sand soil. The conducted tests include compaction test and unconfined compression strength.

\section{MATERIALS AND EXPERIMENTAL PROCEDURES}

A. Sand Soil

The sandy soil used in this study is natural clean sand, was brought from Rashid city -Egypt. As shown in Fig .1, the soil classified as poorly graded sand (SP) according to the Unified Soil Classification System. The main physical properties of used sand determined according to the ASTM standards and was illustrated in Table I.

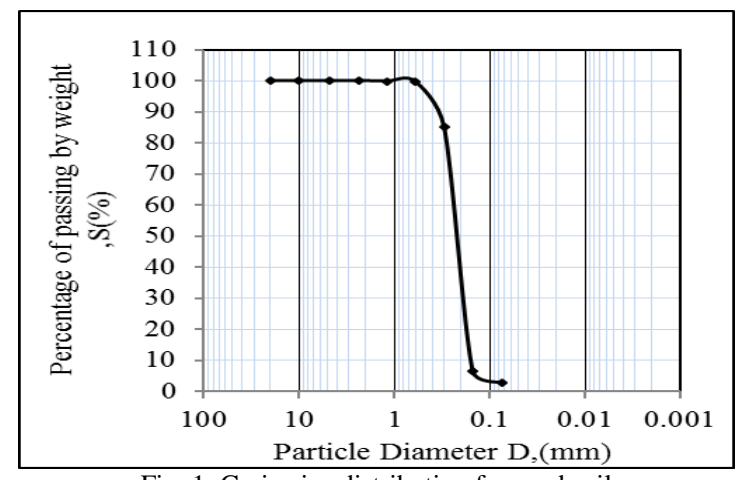

Fig. 1. Grain size distribution for sand soil

TABLE I

MECHANICAL PROPERTIES OF SAND SOIL

\begin{tabular}{|l|l|}
\hline Specific gravity, $\mathrm{G}_{\mathrm{s}}$ & 2.548 \\
\hline Uniformity coefficient, $\mathrm{C}_{\mathrm{u}}$ & 1.61 \\
\hline Coefficient of curvature $\mathrm{C}_{\mathrm{c}}$ & 0.96 \\
\hline Maximum dry unit weight, $\mathrm{KN} / \mathrm{m}^{3}$ & 16.86 \\
\hline Minimum dry unit weight, $\mathrm{KN} / \mathrm{m}^{3}$ & 14.06 \\
\hline Optimum moisture content, $\mathrm{W}_{\mathrm{c}} \%$ & $14 \%$ \\
\hline
\end{tabular}




\section{B. Kaolin clay}

Kaolin clay is industrial clay brought from kaolin stonepits in Egypt which grinded and packaged by Elbasatin company. Hydrometer analysis was performed to obtain the grain size distribution curve of kaolin soil as grain sizes are too small for sieve analysis, and based on Unified Soil Classification System (USCS), the kaolin was classified as low plasticity clay (CL). The physical properties of kaolin used are summarized in Table II, and the chemical properties summarized in Table III. Grain size distribution curve of kaolin is plotted as presented in Fig. 2.

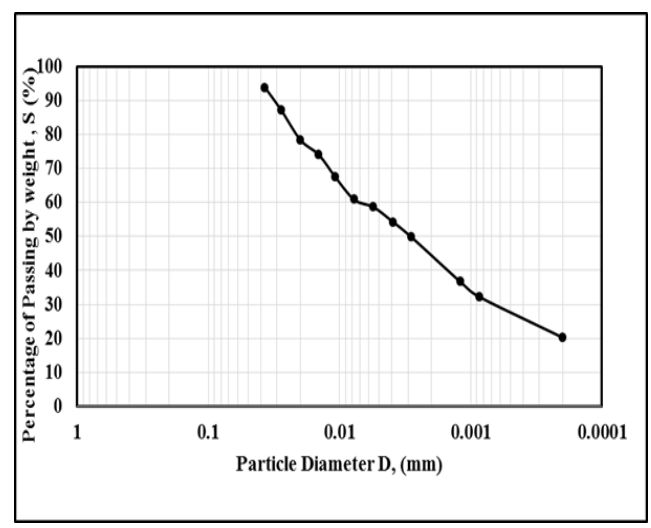

Fig. 2. Grain size distribution for kaolin clay.

TABLE II

PHYSICAL PROPERTIES OF THE USED KAOLIN CLAY

\begin{tabular}{|l|l|}
\hline Liquid limit, L.L \% & $29.4 \%$ \\
\hline Plastic limit, P.L \% & $15 \%$ \\
\hline Plasticity Index, P.I \% & $14.4 \%$ \\
\hline Specific gravity, $\mathrm{G}_{\mathrm{s}}$ & 2.7 \\
\hline
\end{tabular}

TABLE III

CHEMICAL PROPERTIES OF THE USED KAOLIN (ACCORDING TO THE MANUFACTURER'S DATA SHEET)

\begin{tabular}{|c|c|}
\hline Element & Result (\%) \\
\hline Silicon dioxide $\left(\mathrm{siO}_{2}\right)$ & $50-56 \mathrm{max}$ \\
\hline Aluminium oxide $\left(\mathrm{Al}_{2} \mathrm{O}_{3}\right)$ & $30-33 \mathrm{~min}$ \\
\hline Iron oxide $\left(\mathrm{Fe}_{2} \mathrm{O}_{3}\right)$ & $1.0-1.3$ \\
\hline Titanium dioxide $\left(\mathrm{TiO}_{3}\right)$ & $1.3-1.8$ \\
\hline Calcium oxide $(\mathrm{CaO})$ & $0.10-0.25$ \\
\hline Magnesium oxide $(\mathrm{MgO})$ & $0.05-0.10$ \\
\hline Sodium oxide $\left(\mathrm{Na}{ }_{2} \mathrm{O}\right)$ & $0.07-0.15$ \\
\hline Potassium oxide $\left(\mathrm{k}_{2} \mathrm{O}\right)$ & $0.03-0.06$ \\
\hline Chlorine $(\mathrm{Cl})$ & $11-12$ \\
\hline Loss on ignition $\left(10^{\circ} \mathrm{C}-100{ }^{\circ} \mathrm{C}\right)$ & $<.05$ \\
\hline
\end{tabular}

\section{Portland cement}

Ordinary Portland cement from Suez company CEM( I ) grade $42.5 \mathrm{~N}$ was used in this study.

\section{TESTING METHODOLOGY}

Due to the difficulty of finding a clayey sand soil in natural case that enables us to study it, an artificial soil was prepared in laboratory by mixing kaolin clay with oven dried sand at two percentages of clay $20 \%$ until we get a homogenous mixture, then we get geotechnical properties of the soil. Based on historical laboratory and theoretical investigations relative density and its resultant void ratio is one of the effective factors on soil mechanical behaviour and shear strength. In this study all specimens were tested at relative density $55 \%$ and optimum moisture content. The reinforced and unreinforced soil specimens used in tests were prepared by hand mixing and the amount cement and water added as a percentage of the dry weight of soil.

In reinforced samples with cement the amount of cement was calculated based on the mass of dry soil plus the mass of cement and optimum water content of compacted cemented soil. The specimens used in the unconfined compression strength test were prepared in cylindrical split moulds, which were lubricated to facilitate the extraction of the samples after formation. Visual examination of exhumed specimens proved the mixtures to be satisfactorily uniform. After mixing sufficient materials for one specimen, the mixture was stored in a covered container to avoid moisture losses before subsequent compaction.

The undercompaction process, as proposed by ladd, 1978 [3], was used to produce homogenous specimen that could be used in a parametric study in the laboratory testing program. By using this method, the specimens were statically compacted in five layers with tamping into a $38 \mathrm{~mm}$ diameter by $76 \mathrm{~mm}$ height split mould, to relative density of $55 \%$ at optimum moisture content. The top surface between layers was slightly scratched to obtain a homogenous specimen and eliminate as possible the risk of weak shear planes at the contact surface between layers. The samples were then placed within plastic bags to avoid significant variation of moisture content before testing. For reinforced samples with cement they were cured in humid room at temperature of $22^{\circ} \pm 2^{\circ}$ for 7 and 14 days.

\section{TESTING PROGRAM}

Laboratory work included compaction, and unconfined compressive strength (UCS) tests. The tests were performed on pure sand and $80 \%$ sand soil with $20 \%$ kaolin. All the tests in this study were performed according to the procedures described in the ASTM standards. In this study, the effect of adding kaolin clay on sand soil. Compaction test was conducted to determine the change in maximum dry density and optimum moisture content. The compaction curves were determined according to the ASTM, D 1557 [4]. Also, the unconfined compression strength of the clayey soil were obtained according to the ASTM-D 2166 [5]. The amounts of cement added to the soil samples as a percentage of the dry soil mass were $(1 \%, 2 \%$, and $3 \%)$, and the specimens examined after 2 hours from preparation ,7 days and 14 days.

\section{TEST RESULTS}

\section{A. Influence of kaolin content on compaction characteristics}

It is clearly observed that adding kaolin clay increases the maximum dry unit weight and decreases the optimum moisture content, this takes place because fine particles of kaolin fill the voids between the sand particles increasing the density. The obtained values of maximum dry density and optimum moisture content versus kaolin content in soil are presented in Fig. 3. 


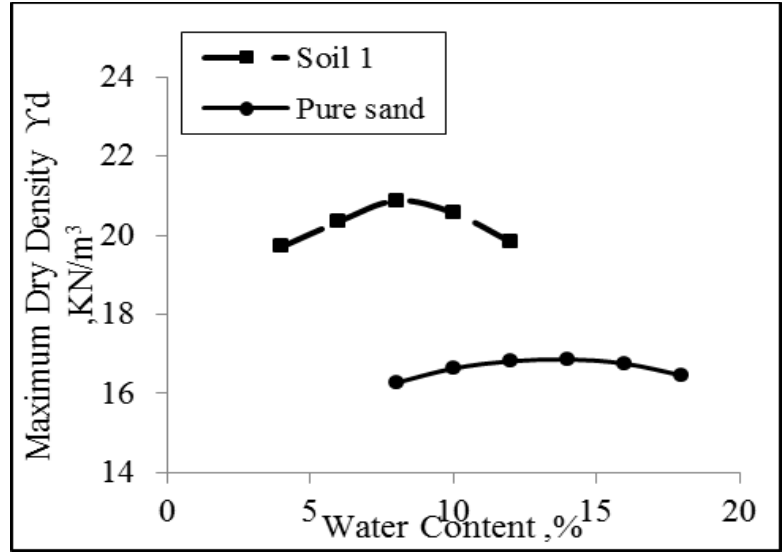

Fig. 3. Compaction curves for pure sand and added kaolin

\section{B. Influence of cement content on compaction characteristics}

The results showed that the addition of cement increases both of the maximum dry unit weight and the optimum moisture content because of binding of cement particles between voids of soil. That because of the mixing of cement with cohesive soil, the calcium ions released during the initial cement hydration reaction are marked to scale back the soil plasticity. The mechanism is presumably the cation exchange or crowding of additional cations onto the soil, and when soilcement is compacted, chemical bonds develop between adjacent cement grain surfaces and between cement grain and soil particle interfaces. In fine-grained silty and clayey soils, cement hydration develops strong linkages between the mineral and therefore the aggregates to make a honeycombtype structure whereby the particles of soil cannot slide over one another. The results for soil are plotted in Fig.4.The values of each cement content and the corresponding value of maximum dry unit weight and the optimum moisture content summarized in Table IV.

\section{Influence of cement content on UCS}

Adding cement increases Unconfined compression strength and axial strain but in low rate, so it is important to study the time effect after curing cemented samples for 7 days and 14 days ,test results show a significant increase in unconfined compression strength and axial strain, and observed a decrease in the time of failure. As a result of that Unconfined compression strength increases with time for cemented soil, but axial strain decreases, which make the soil more stiff due to the chemical effect of cement (hydration effect). The values of each cement contents and the corresponding value of unconfined compression strength and axial strain were summarized in Tables (V and VI )and Figures (5,6, and 7). The improvement in unconfined compression strength and axial strain for are shown in Figures (8 and 9). From analysis of results percent of improvement in maximum unconfined compression strength due to cement addition is $65 \%$, and the percent of improvement in axial is $53.14 \%$.Time factor plays an important role because of hydration of cement in samples which increases the unconfined compression strength and decreasing axial strain which make the samples more stiff.

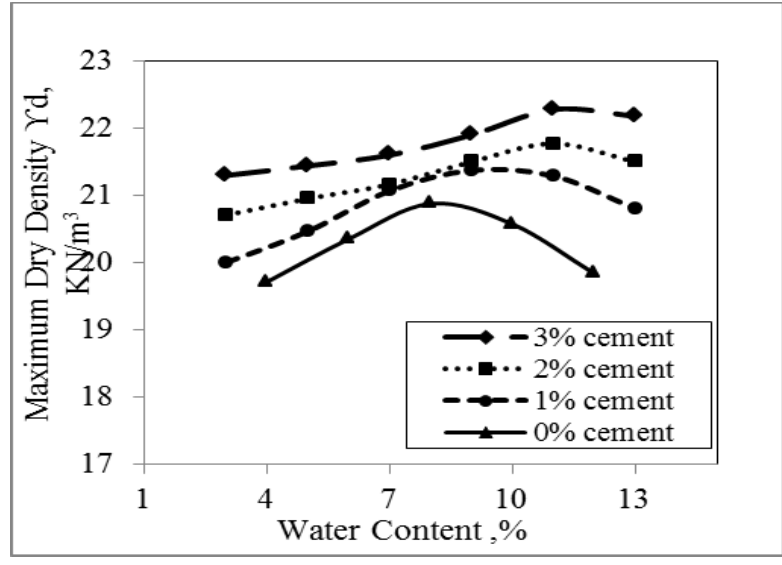

Fig. 4. Compaction curves for cement contents

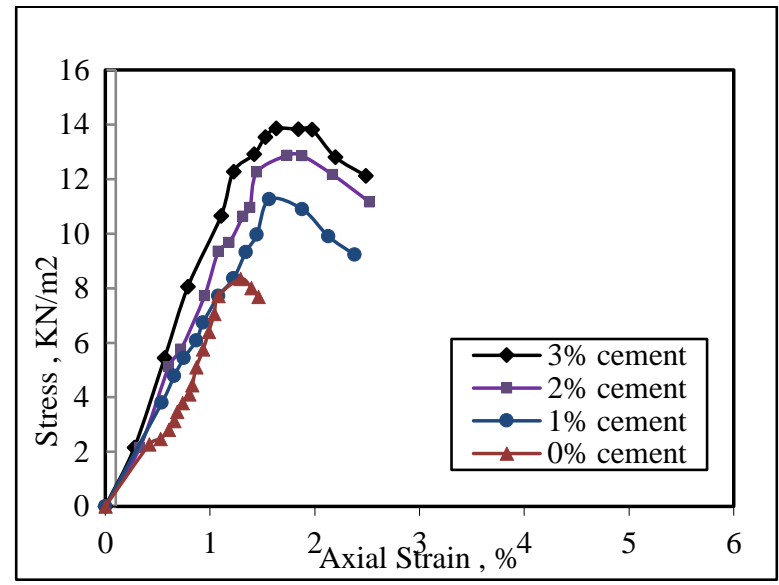

Fig. 5. Stress-strain curve for cemented soil after 2 hours from preparation

TABLE IV

CEMENT CONTENT AND CORRESPONDING Y $_{\mathrm{dmax}} \& \mathrm{WC}$

\begin{tabular}{|c|c|c|}
\hline Cement Content $\%$ & $\gamma_{\mathrm{dmax}}, \mathrm{kN} / \mathrm{m}^{3}$ & $\mathrm{~W}_{\mathrm{C}}, \%$ \\
\hline 0 & 20.88 & 8.2 \\
\hline 1 & 21.37 & 9.5 \\
\hline 2 & 21.77 & 10.6 \\
\hline 3 & 22.28 & 11.65 \\
\hline
\end{tabular}

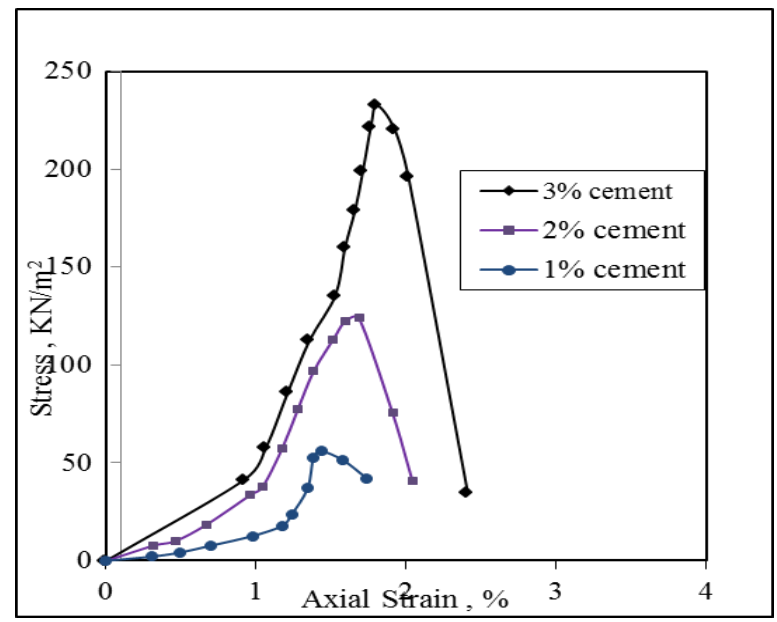

Figure 6. Stress-strain curve for cemented soil after 7 days 


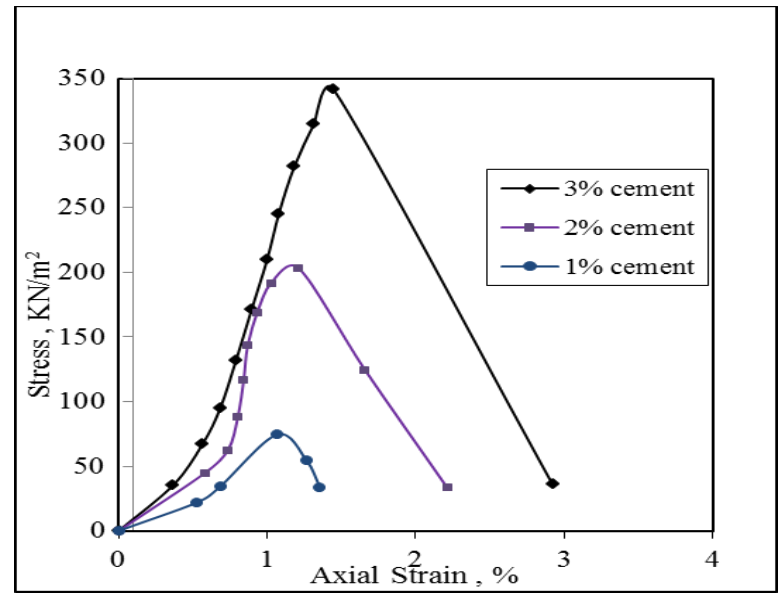

Fig. 7. Stress-strain curve for cemented soil after 14 days

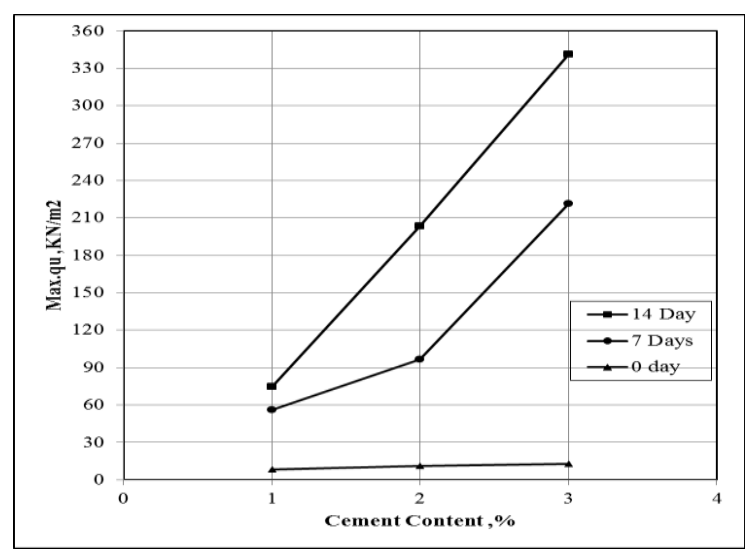

Fig. 8. Improvement in UCS after curing the specimens

TABLE V

CEMENT CONTENT AND CORRESPONDING Max . $\mathrm{q}_{\mathrm{u}}$

\begin{tabular}{|c|c|c|c|}
\hline \multicolumn{2}{|c|}{ Cement Content $\%$} & \multicolumn{2}{c|}{ Max. $\mathrm{qu}_{\mathrm{u}}\left(\mathrm{KN} / \mathrm{m}^{2}\right)$} \\
\hline & 0 & 7 days & 14 days \\
\hline 0 & 8.262 & ----- & ----- \\
\hline 1 & 11.294 & 55.641 & 74.504 \\
\hline 2 & 12.737 & 113.086 & 203.333 \\
\hline 3 & 13.711 & 220.728 & 342.070 \\
\hline
\end{tabular}

TABLE VI

CEMENT CONTENT AND CORRESPONDING AXIAL STRAIN

\begin{tabular}{|c|c|c|c|}
\hline \multicolumn{2}{|c|}{ Cement Content $\%$} & \multicolumn{2}{c|}{ Axial strain , $\%)$} \\
\hline & 0 & 7 days & 14 days \\
\hline 0 & 1.289 & ----- & ----- \\
\hline 1 & 1.566 & 1.434 & 1.066 \\
\hline 2 & 1.882 & 1.684 & 1.211 \\
\hline 3 & 1.974 & 1.803 & 1.276 \\
\hline
\end{tabular}

\section{Observations of failure shapes}

From examination of failed un-reinforced specimens the failure surfaces were planar and closely to the surface because the specimen without reinforcement is loose and don't carry the pressure applied on it. In contrast and for specimens stabilized with cement failure behavior becomes brittle failure or shear failure because the cement hydrate in the specimen increasing bond but making the sample more stiff ,so the failure happens in sudden shape due to sliding the particles around the shear plan, as in Fig. 10.

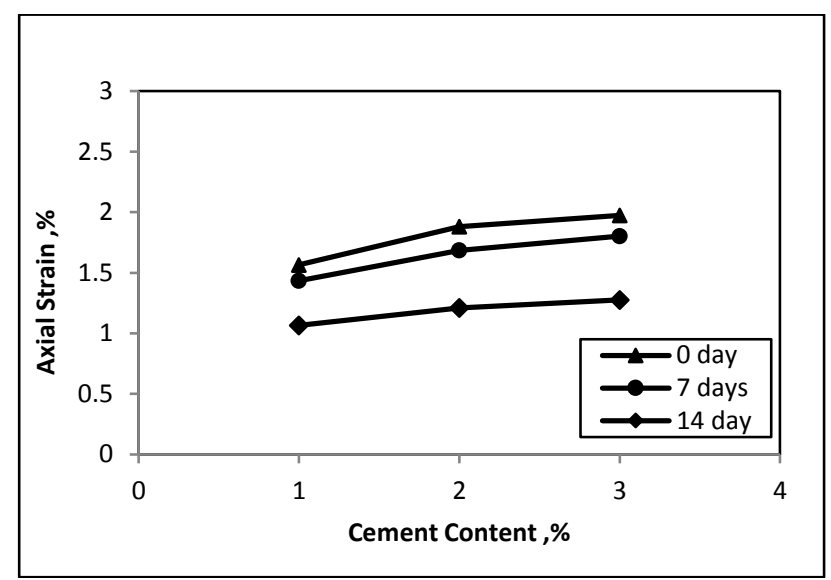

Fig. 9. Improvement in axial strain with cement content

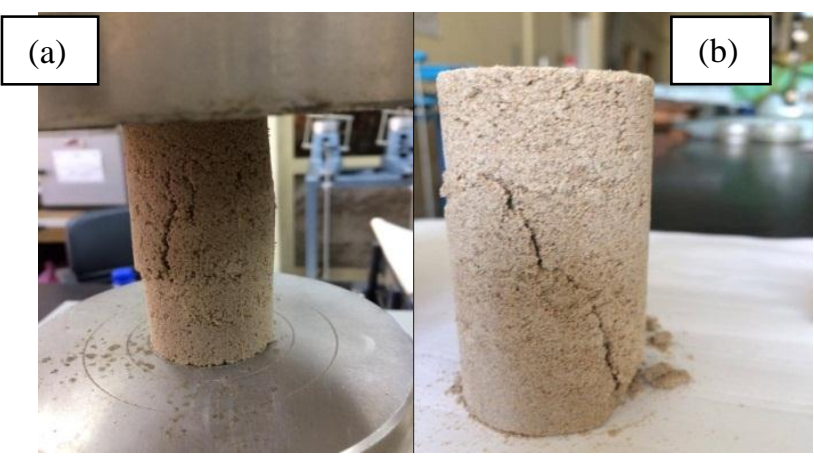

$\begin{array}{ll}\text { (a) unreinforced sample } & \text { (b) } 3 \% \text { cemented sample . }\end{array}$

Fig. 10. Improvement in axial strain with cement content

\section{CONCLUSION}

This paper has analyzed the change in soil characteristics when adding cement on artificial clayey sand soil. Based on the test results and analysis, the following conclusions are drawn:

1. It was found that kaolin content influences on compaction characteristics which increases maximum dry density by $23.78 \%$ and reduces optimum moisture content by $70.73 \%$.

2. Adding cement influence on compaction characteristics, since it increases maximum dry density and optimum moisture content by $6.7 \%$ and $42.07 \%$ respectively at the percent of $3 \%$ cement.

3. Unconfined compression strength increases with the increase in cement content to $3 \%$ by $65.95 \%$ after 2 hours from preparation.

4. Unconfined compression strength increases with time for cemented soil at percent $3 \%$ the maximum compression strength increased from $13.711 \mathrm{KN} / \mathrm{m}^{2}$ to $324.07 \mathrm{KN} / \mathrm{m}^{2}$ after 14 days .

5. The behavior of specimens with higher cement contents is more brittle compared to specimens with lower cement contents which the axial strain decreases by $54.7 \%$ at cement content $3 \%$. 
6. Failure mode in cemented stabilized specimens is brittle failure due to stiffness of specimens.

\section{REFERENCES}

[1] Consoli, N.C., Prietto, P.D.M., Ulbrich, L.A., 1998. "Influence of fiber and cement addition on behavior of sandy soil. Journal of Geotechnical and Geoenvironmental Engineering 124 (12), 1211-1214.

[2] Asskar Janalizadeh Choobbasti, Saman Soleimani Kutanaei, Mobina Taslimi Paein Afrakoti. (2019) Modeling of compressive strength of cemented sandy soil. Journal of Adhesion Science and Technology 33:8, pages 791-807.

[3] Ladd RS. Preparing test specimens using undercompaction. Geotech Test J ASTM. 1978;1:16-23.

[4] Designation: D 1557. 2008, "Standard test methods for laboratory compaction characteristics of soil using modified effort", American society for testing and materials (ASTM), pp. 14

[5] Consoli NC, Bassani MAA, Festugato L. Effect of fiberreinforcement on the shear strength of cemented soils. Geotext Geomembr. 2010;28:344-351.

[6] Maher MH, Ho YC. Behavior of fiber-reinforced cemented sand under static and cyclic loads. Geotech Test J. 1993;16:330-338.

[7] Tang C, Shi B, Gao W, et al. Strength and mechanical behavior of short polypropylene fiber reinforced and cement stabilized clayey soil. Geotext Geomembr. 2007;25:194-202.
[8] Consoli NC, Montardo JP, Donato M, et al. Effect of material properties on the behavior of sand-cement-fiber composites. Ground Improvement. 2004;8:77-90.

[9] Hamidi A, Hooresfand M. Effect of fiber reinforcement on triaxial shear behavior of cement treated sand. Geotext Geomembr. 2013;36:1-9.

[10] Park SS. Effect of fiber reinforcement and distribution on unconfined compressive strength of fiber-reinforced cemented sand. Geotext Geomembr. 2009;27:162-166.

[11] Kutanaei SS, Choobbasti AJ. Prediction of combined effects of fibers and cement on the mechanical properties of sand using particle swarm optimization algorithm. J Adhes Sci Technol. 2015;29:487-501.

[12] Tang C, Wang D, Cui Y, et al. Tensile strength of fiberreinforced soil. J Mater Civ Eng. 2016;28:04016031.

[13] Cai Y, Shi B, Ng CWW, et al. Effect of polypropylene fibre and lime admixture on engineering properties of clayey soil. Eng Geol. 2006;87:230-240.

[14] Clough GW, Sitar N, Bachus RC, et al. Cemented sands under static loading. J Geotech Eng Div. 1981;107:799-817.

[15] Yang Z. Strength and deformation characteristics of reinforced sand [PhD thesis]. Los Angeles (CA): University of California; 1972.

[16] Dehghan A, Hamidi A. Impact of fiber reinforcement on deformation characteristics of cemented sand-gravel mixtures. J Eng Geol. 2015;9:2695-2710. 